\title{
Nigella sativa Infusion as an Antioxidant Agent Against Gentamicin- Induced Kidney Damaged in Mice
}

\author{
Hamsiah binti Halim ${ }^{1}$, Achadiyani ${ }^{2}$, Tjahjodjati ${ }^{3}$ \\ ${ }^{1}$ Faculty of Medicine, Universitas Padjadjaran, ${ }^{2}$ Department of Biology Cell, Faculty of Medicine, \\ Universitas Padjadjaran, ${ }^{3}$ Department of Urology, Faculty of Medicine, Universitas Padjadjaran/ \\ Dr. Hasan Sadikin Hospital Bandung
}

\begin{abstract}
Background: Gentamicin is one of the most common antibiotics related to nephrotoxicity. It has been proposed that the nephrotoxicity is associated with the generation of the reactive oxygen species. Thymoquinone, an active compound of Nigella sativa, shows to have an antioxidant property. The study aims to identify the possible nephroprotective action of Nigella sativa infusion against gentamicin-induced kidney damaged in mice.

Methods:This experimental study was carried out in the Department of Cell Biology Laboratory, Universitas Padjadjaran, Bandung from 10th November 2012 to 14th December 2012. There were four groups, each consisting of 6 mice. Group I (control negative), group II (gentamicin $100 \mathrm{mg} / \mathrm{kg}$ ), group III (3.9 mg Nigella sativa infusion+gentamicin $100 \mathrm{mg} / \mathrm{kg}$ ) and group IV $(7.8 \mathrm{mg}$ Nigella sativa infusion+gentamicin $100 \mathrm{mg} /$ $\mathrm{kg}$ ). The kidneys were evaluated histopathologically by light microscope. The percentage average number of normal proximal tubules in group I and the percentage average number of proximal tubules damaged in group II, III and IV were measured.

Results: The results showed the percentage average number of the proximal tubules damaged in group II, III and IV were $14.53 \%, 7.49 \%$ and $3.94 \%$ respectively. Significant differences were observed between group II and III, group II and IV, and group III and IV.
\end{abstract}

Conclusion: Nigella sativa infusion protects against gentamicin-induced kidney damage in mice. [AM].2014;1(2):90-3]

Keywords: Gentamicin, kidney, Nigella sativa infusion

\section{Infusa Nigella sativa sebagai Antioksidan Terhadap Kerusakan Ginjal pada Tikus yang Diinduksi Gentamisin}

\section{Abstrak}

Latar Belakang: Gentamisin adalah salah satu antibiotik yang paling sering dihubungkan dengan nefrotoksisitas. Nefrotoksisitas yang terjadi berhubungan dengan pembentukan reactive oxygen species. Thymoquinone, senyawa aktif Nigella sativa, telah terbukti memiliki sifat antioksidan. Penelitian ini bertujuan untuk mengidentifikasi sifat nefroprotektif infusa Nigella sativa terhadap kerusakan ginjal pada tikus yang diinduksi gentamisin.

Metode: Penelitian eksperimental ini dilakukan di Laboratorium Departemen Biologi Sel, Fakultas Kedokteran, Universitas Padjadjaran, Bandung dari 10 November 2012 -14 Desember 2012. Ada empat kelompok masing-masing terdiri atas 6 tikus. Kelompok I (control negatif), kelompok II (gentamisin 100 $\mathrm{mg} / \mathrm{kg})$, kelompok III (3,9 mg infusa Nigella sativa+gentamisin 100mg/kg) dan kelompok IV (7,8 mg infusa Nigella sativa+gentamisin $100 \mathrm{mg} / \mathrm{kg}$ ). Ginjal kemudian dievaluasi secara histopatologi dengan mikroskop cahaya. Persentase rata-rata jumlah tubulus proksimal yang normal dalam kelompok I dan persentase ratarata jumlah tubulus proksimal rusak dalam kelompok II, III dan IV diukur.

Hasil: Persentase rata-rata jumlah tubulus proksimal rusak dalam kelompok II, III dan IV adalah 14,53\%, 7,49\% dan 3,94\%. Perbedaan signifikan yang diamati adalah pada kelompok II dengan III, kelompok II dengan IV, serta kelompok III dan IV.

Correspondence: Hamsiah binti Halim, Faculty of Medicine, Universitas Padjadjaran, Jalan Raya Bandung-Sumedang Km.21, Jatinangor, Sumedang, Indonesia, Phone: +6283820119781, Email: hamsiah_halim@yahoo.com 
Simpulan: Infusa Nigella sativa melindungi terhadap kerusakan ginjal yang diinduksi gentamisin pada tikus. [AMJ.2014;1(2):90-3]

Kata kunci: Gentamisin, ginjal, infusa Nigella sativa

\section{Introduction}

Gentamicin antibiotic is widely used to treat life-threatening infections caused by negative bacteria. However, it can cause nephrotoxicity. Oxidative stress and nitrosative stress have been reported to contribute the nephrotoxicity. As a result, its clinical use is limited.1Nephrotoxicity induced by gentamicin is an essential cause of renal failure. ${ }^{2}$ Approximately $10-15 \%$ of all cases of acute renal failure are due to the gentamicin nephrotoxicity. ${ }^{3}$ Metabolite products of the gentamicin are excreted through kidney. It may cause damage to the renal cells and resulting in renal dysfunction. ${ }^{4}$

The nephrotoxicity is due to the accumulation of the drug in the renal cortex. Receptors in the proximal tubule cells are able to transport the drug into the cells through endocytosis. Accumulation of the gentamicin in the cells disrupt cellular functions that results in apoptosis and necrosis of the proximal tubule. Ultimately, acute kidney injury occurs. ${ }^{5}$ Direct necrosis of the tubules are the characterization of the gentamicininduced nephrotoxicity, which occur mainly in proximal tubules. ${ }^{6}$

Nigella sativa is one of the promising medicinal plants with many historical and religious backgrounds for curing several diseases. ${ }^{7}$ The principle active compound of Nigella sativa is thymoquinone. Thymoquinone has most prominent activity of antioxidant. It neutralizes oxygen radicals by acting as an anion scavenger.8 This study was conducted to analyze the nephroprotective effect of Nigella sativa infusion against gentamicin-induced kidney damaged in mice.

\section{Methods}

This experiment was carried out in Animal Laboratory of Department of Cell Biology in Universitas Padjadjaran, Bandung from November 2012 to December 2012. A bottle of Nigella sativa containing powdered-capsules was purchased in Bandung Indah Plaza (BIP), Bandung. Gentamicin was obtained from the General Hospital Dr. Hasan Sadikin General
Hospital Bandung. GalurBalb C strain mice (25-30g each) aged 7-8 weeks, healthy, and white male were used in this study. The mice were housed in homogenous temperature and dark-light cycle for 7 days (adaptation period) with unlimited to drink and food.

In this study, Nigella sativa infusion was made from the Nigella sativa powders. Nigella sativa powders were weighed to $3.9 \mathrm{mg}$ and $7.8 \mathrm{mg}$. Then the powders were added into a container containing $100 \mathrm{ml}$ of aquadest. The infusion was brought to a boil and simmered for 15 minutes until the temperature reaches $90^{\circ} \mathrm{c}$. After the infusion cooled down, it was filtered using filter paper into a beaker.

Four groups of six mice each were used for the study. Group I, served as control negative, received isotonic normal saline throughout the experiment. Group II, served as control positive, received intraperitoneal injection of gentamicin $100 \mathrm{mg} / \mathrm{kg} /$ day for 8 days. Group III received gentamicin $100 \mathrm{mg} / \mathrm{kg} /$ day (intraperitoneally) for eight days and $3.9 \mathrm{mg}$ of Nigella sativa infusion for ten consecutive days. Group IV received gentamicin $100 \mathrm{mg} /$ $\mathrm{kg} /$ day (intraperitoneally) for eight days and $7.8 \mathrm{mg}$ of Nigella sativa infusion for ten consecutive days.

On the $11^{\text {th }}$ day, the mice were sacrificed. The kidneys of the mice were collected for histopathological examinations after sacrifice. The kidneys were fixed in $10 \%$ of formalin solution and embedded in paraffin wax. The paraffin wax was cut into 5 micrometer sections and was stained with hematoxylin and eosin. The tissues were then examined under light microscope and the number of normal proximal tubules in group I and the number of proximal tubules damaged in group II, III and IV were measured.

The data were expressed as average and percentage. The significance of differences among the four groups was assessed using Kruskal-Wallis followed by post-hoc Mann Whitney. The $\mathrm{p}$ value $<0.05$ indicated significant differences.

\section{Results}

The average number of normal proximal tubules in group control negative was 56.10 
Table 1 Average normal and damaged proximal tubules

\begin{tabular}{cccc}
\hline $\begin{array}{c}\text { Average normal } \\
\text { proximal tubules }\end{array}$ & $\begin{array}{c}\text { Average proximal tubules } \\
\text { damaged }\end{array}$ & $\begin{array}{c}\text { Percentage of the average proximal } \\
\text { tubules damaged }\end{array}$ & p \\
\hline \multirow{2}{*}{ Group $1=56.10$} & Group 2 $=8.15$ & $14.53 \%$ & $0.000^{*}$ \\
& Group $3=4.20$ & $7.49 \%$ & \\
\hline
\end{tabular}

Note: *Kruskal Wallis Test, \% of the average proximal tubules damaged= Average proximal tubules damaged divided Average normal proximal tubules in group multiplied $100 \%$

(Table 1). The average number of proximal tubules damaged in gentamicin-treated mice was 8.15 (14.53\%). Gentamicin plus 3.9 mgof Nigella sativa infusion treated mice showed significant decreases in the average of the proximal tubules damaged. The average of the proximal tubules damaged was $4.20(7.49 \%)$. Also, there was a significant decrease in group 4 which received gentamicin and 7.8 mg of Nigella sativa infusion. The average number of proximal tubules damaged in group 4 was 2.21 (3.94\%).

Kruskal-Wallis test was used because there was anomaly in data distribution. The results showed that at least there was a significant difference among groups.

However, to know which group has significant differences in average of proximal tubules damaged, further tests must be conducted. For Kruskal-Wallis test, the post hoc is Mann-Whitney. When compared to positive group, there was significant difference in the group given Nigella sativa infusion. In addition, significant differences between the two dosages of Nigella sativa (3.9 mg and 7.8 mg) were observed.

\section{Discussion}

Gentamicin is aminoglycosides antibiotic commonly used against serious gramnegative bacterial infections. However, the antibiotic could result in nephrotoxicity. Therefore, its clinical use is limited. ${ }^{1}$ Gentamicin nephrotoxicity causes around $10-15 \%$ of all acute renal failure cases. ${ }^{3}$ It is believed that the accumulation of the drug in the renal cortex plays an essential role in nephrotoxicity.

The cells of the proximal tubules have receptors that are capable of transporting gentamicin into the cells through endocytosis. ${ }^{5}$ There are many factors which influence binding of the drug to biological membranes. For instance, ischemia favors the binding of the drug. However, it is competitively inhibited by $\mathrm{Ca} 2+.{ }^{1}$ Furthermore, there are interactions between gentamicin with cellular structures for examples mitochondria, lysosomes and microsomes. ${ }^{3}$

Since the gentamicin concentrates in the proximal tubule cells, it disrupts cellular functions that results in the apoptosis and necrosis of the cells. Hence, acute kidney injury occurs. ${ }^{5}$ Apoptosis plays a role in the cell death leading to the removal of the cells which are damaged. ${ }^{9}$ From the previous research, an experiment with animals treated with gentamicin shows the presence of apoptosis 10 and necrosis11 of tubular epithelial cells in vivo as well as in cultured cells. ${ }^{12}$ In this study, mice treated with gentamicin also showed damage to the tubular epithelial cells as the main renal morphological changes.

The nephrotoxicity has been reported due to the role of oxidative stress.1Reactive oxygen species (ROS) has been suggested as the main key in the mechanisms that results in the necrosis of the tubular cells and the reduction in glomerular filtration rate. ${ }^{13}$ In the presence of the polyunsaturated lipids in the vitro studies, gentamicin stimulates the production of the ROS that could contribute to the kidney injury. ${ }^{14}$ Gentamicin changes the glomerular filtration rate. The changes are due to the contraction of the mesangial cell, glomerular filtration barrier selectively loss because of the neutralization by its negative charges, proliferation of mesangial cell and apoptosis. ${ }^{13}$

Nigella sativa has been used to treat many diseases. The investigations of the pharmalogical use of the seeds have been conducted in many researches. From the previous research, it is found that Nigella sativa exhibits anti-inflammatory, antioxidant, and anti-microbial properties. ${ }^{15}$ Generation of the free radicals are important cause of renal injury induced by gentamicin antibiotic16. Accordingly, the use of Nigella sativa infusion with its antioxidant properties in this study 
may have protective effect against gentamicininduced nephrotoxicity.

Nigella sativa seeds have demonstrated protective effect against $\mathrm{CCl} 4$-induced liver damaged in experimental animals. From previous studies, thymoquinone, one of the active compounds of Nigella sativa was found to have antioxidant properties. ${ }^{8}$ Over 35 studies have been focused on antitoxic properties of thymoquinone in vivo and in vitro. ${ }^{7}$ Thymoquinone is said to have potent scavenger activities against free radicals. It neutralizes oxygen radicals by acting as an anion scavenger.

In this study, the administration of Nigella sativa infusion ameliorated nephrotoxicity of gentamicin. The average number of proximal tubule damage in the prophylactic treatment of mice with Nigella sativa one hour before the gentamicin $100 \mathrm{mg} / \mathrm{kg}$ injection was reduced. It may be due to the action of the thymoquinone as antioxidant protecting renal from gentamicin nephrotoxicity.

In conclusion, Nigella sativa infusion protects renal from damage due to gentamicin nephrotoxicity.

\section{References}

1. Dhanarajan $\mathrm{R}$, Abraham $\mathrm{P}$, Isaac $\mathrm{B}$. Protective effect of ebselen drug, against gentamicin-induced renal damage in Rats. Basic Clin Pharmacol Toxicol. 2006;99(3):267-72.

2. Perazella MA. Drug-induced renal failure: update on new medications and unique mechanisms of nephrotoxicity. Am J Med Sci. 2003;325(6):349-62.

3. Rincon J, Romero M, Viera N, Pedreanea $\mathrm{A}$, Mosquera J. Increased oxidative stress and apoptosis in acute puromycin aminonucleoside nephrosis. Int J Exp Pathol. 2004;85(1):25-33.

4. Naughton CA. Drug induced nephrotoxicity. Am Fam Physician. 2008;78(6):743-50.

5. Mladen K. Drug-induced kidney injury. eJIFCC. 2009;20(1).

6. PedrazaChaverri J, Gonzalez Orozco AE, Maldonado PD, Barrera D, Medina-Campos ON, Hernández-Pando R. Diallyl disulfide ameliorates gentamicin-induced oxidative stress and nephropathy in rats. Eur J Pharmacol. 2003;473(1): 71-8.

7. Salem ML. Immunomodulatory and therapeutic properties of the Nigella sativa L. seed. Int Immunopharmacol. 2005;5(13-14):1749-70.

8. Ragheb A, Attia A, Eldin WS, Elbarbry F, Gazarin S, Shoker A. The protective effect of thymoquinone, an anti-oxidant and anti-inflammatory agent, against renal injury: a review. Saudi J Kidney Dis Transpl. 2009;20(5):741-52.

9. Servais H, Van Der Smissen P, Thirion G, Van Der Essen G, Van Bambeke F, Tulkens PM. Gentamicin-induced apoptosis in LLCPK1 cells: involvement of lysosomes and mitochondria. Toxicol Appl Pharmacol. 2005;206:321-33.

10. Li J, Li QX, Xie XF, Ao Y, Tie CR, Song RJ. Differential roles of dihydropyridine calcium antagonist nifedipine, nitrendipine and amlodipine on gentamicin-induced renal tubular toxicity in rats. Eur J Pharmacol. 2009;620:97-104.

11. Edwards J, Diamantakos E, Peuler J, Lamar P, Prozialeck W. A novel method for the evaluation of proximal tubule epithelial cellular necrosis in the intact rat kidney using ethidium homodimer. BMC Physiol. 2007;7:1.

12. Pessoa E, Convento M, Silva R, Oliveira A, Borges F, Schor N. Gentamicin-induced preconditioning of proximal tubular LLCPK1 cells stimulates nitric oxide production but not the synthesis of heat shock protein. Braz J Med Biol Res. 2009;42:614-20.

13. Lopez-Novoa JM, Quiros Y, Vicente L, Morales AI, Lopez-Hernandez FJ. New insights into the mechanism of aminoglycoside nephrotoxicity: an integrative point of view. Kidney Int. 2011;79:33-45.

14. Lesniak W, Pecoraro VL, Schacht J. Ternary complexes of gentamicin with iron and lipid catalyze formation of reactive oxygen species. Chem Res Toxicol. 2005;18:35764.

15. Bayrak O, Bavbek N, Karatas OF, Bayrak R, Catal F, Cimentepe E, Akbas A, Yildirim E, Unal D, Akcay A. Nigella sativa protects against ischaemia/reperfusion injury in rat kidneys. Nephrol Dial Transpl. 2008;23(7):2206-12.

16. Kadkhodaee $M$, Khastar $H$, Faghihi $M$, Ghaznavi R, Zahmatkesh M. Effects of cosupplementation of vitamins $\mathrm{E}$ and $\mathrm{C}$ on gentamicin-induced nephrotoxicity in rat. Exp Physiol. 2005;90:571-6. 